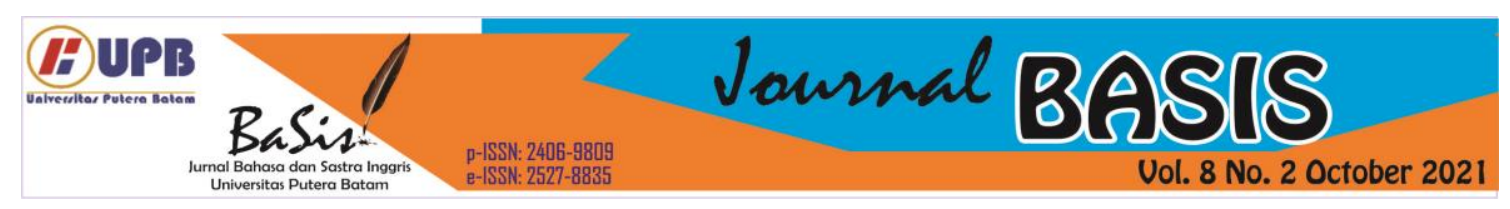

\title{
HOW TEENAGERS PERCEIVE LANGUAGE AS A PART OF CULTURE: PROTOTYPE SEMANTIC APPROACH
}

\author{
Muhammad Hafiz Kurniawan ${ }^{1}$ \\ Universitas Ahmad Dahlan (UAD), Yogyakarta, Indonesia \\ muhammad.kurniawan@enlitera.uad.ac.id $^{1}$ \\ Syihabuddin $^{2}$ \\ Universitas Pendidikan Indonesia (UPI), Bandung, Indonesia \\ syihabuddin@upi.edu ${ }^{2}$
}

\begin{abstract}
Indonesia is known to have countless varieties of cultures because Indonesia consists of many tribes and languages. Bahasa Indonesia as the national language faces the new threat from the code mixing slang such as kids jaman now, mantap soul, unfaedah, and curigation which is so popular among the teenagers. This research aims to know the perspective of culture among the teenagers by using a semantic prototype which has a focus to know the grade of goodness. This semantic prototype in this research uses two methods in collecting the data, first is using free listing and the second is judging the examples of categorizations to evaluate which of the categories included as culture was positioned among others prototypically. The respondents of this research are 47 respondents for the first method and 52 respondents for the second method and their age range from 18-20 years old. The other questions are also asked to the respondents related to their knowledge about culture. The result of this research is that culture is seen to be something performable on stage such as traditional dance and costume, rites, and music and ironically language in this case is only in $6^{\text {th }}$ position in the first method and $4^{\text {th }}$ position in the second method. Although the position of language changes the acknowledgment of language as an integral part of culture is still low in number.
\end{abstract}

Keywords: Perspective of culture, teenagers, position of language, prototype semantics

\section{INTRODUCTION}

Culture is defined as the whole aspects in society includes knowledge, belief, values, and habits which are acquired by the society member (Tylor, 2016). Although, this is considered general definition of culture (Eriksen, 2006, p.26) the definition of Tylor is rather the same as the process of acquiring language experienced by children which is influenced by their environment (Akmajian et al., 2010, p. 482 ), because language is the part of the culture because it can reflect not only their social, age, gender, class, and ethnic identity (Holmes, 2013, p.337), but also their myths and cultural beliefs through the vocabularies in language ( $\mathrm{p}$. 347-350). However, with the rise of technology, communication among people are limitless and the culture are easily spread through the internet

Nowadays, what makes some scholars and government worries is the concept of nation without borders in cross-cultural communication. The phenomenon which makes English 
global lingua franca cannot be avoided and it has two sides, the positive side which makes people the opportunity to be heard and the negative one which makes non-native speakers in disadvantages (Lacey, 2013). Moreover, with this phenomena, the local languages are threatened because English is considered modern and international language in South East Asian countries, including Indonesia (Kirkpatrick, 2012). English is viewed as the more powerful language in crosscultural communication compared to other languages because English is not only business lingua franca but it is also considered global lingua franca; as a result, the regional language is marginalized because it is only seen as tradition and identity (May, 2015). In Indonesia, Bahasa Indonesia has more power if it is compared to regional language because of its position as the national language. Moreover, Bahasa Indonesia also gains so much international attention i.e. to include Bahasa Indonesia in UK curriculum because it is considered having possible trade priorities for the UK government (Tinsley \& Board, 2013, p.12). However, the dangerous situation which may face Bahasa Indonesia is the awareness of the Indonesian towards Bahasa Indonesia.

Globalization seems to lay its claw onto Bahasa Indonesia which is proved by many improper uses of Bahasa Indonesia by the teenagers; at the same time, the position of English, which is considered as new Dutch in democratic era regarding it in social status (Onishi, 2010, par.15), has been being so popular among the teenagers and even parents to the Indonesian children who send theirs to International school with more focus on English than on Bahasa Indonesia (par. 4-5). This is considered a great extent of threat faced in
Indonesia linguistic legacy. Although learning foreign language is important, being aware of own language is a must to avoid the dangerous threats to language.

One of the examples of this threat is the development of code mixing uses as a slang which recently have been appearing in many occasions and even in online news articles e.g. kids jaman now (Fermansyah, 2017), presiden zaman now (Rochmawati, 2018), teacher jaman now, and un-faedah and other uses of prefix $\{$ un- $\}$ in other words. Although this phenomenon was criticized by Isnaeni (2017) the development of this phrase seems unstoppable, and new phrases and words may appear with that unusual phrases and prefix in Bahasa Indonesia structure from that rules. Moreover, this phenomenon expands and is famous among the teenagers. Creating new words or phrases seems something common to the teenagers to show their identity (Holmes, 2013, p.176) .However, this common use among the teenagers should not be cultured by the media. Instead of doing that, the media should promote how to use Bahasa Indonesia well. The phenomenon mentioned earlier should not be an integral part of teenagers' acquisition in their national language or in the way they create the slang words which can be taken from the richness of their own language rather than to take from other languages. Although this cannot be easily eliminated, the effort to guide the teenagers to be more proud of their own language can be more strengthened.

One of the ways to strengthen the national language promotion is through the research to know the problem about it which should be handled and aware of. This research aims to know the position of language in culture categories. Although language and 
culture cannot be seen as hierarchical system but rather cyclical (Matsumoto \& Juang, 2003, p.263), the way human perceives culture, however, can be in order based on the firstly mentioned by. It is caused by the frequent words will be more easily accessed than infrequent one or it is called as recency effect (Akmajian et al., 2010, p.433-434). Therefore, this research has an aim to know the perception of teenagers towards the words "budaya" or culture; moreover, in this research, the teenagers, who are mostly college students in age between 18-20 years old, were asked about the example of culture based on their view. Moreover, this research also investigate how the teenagers perceive language as the part of the culture, whether it is in the center of the prototype, which means it cannot be separated (Jiang, 2000) or as the best example of culture or it is in the peripheral part.

Research using prototype semantics has been done by researchers such as Rosch et al. (1976) about categorization of basic objects such as musical instrument, fruit, clothing, furniture, and other basic levels. In this research, Rosch et al. (1976) used several steps to measure to gain the data. Researchers who has done the similar research was Fehr \& Russell (1991) and in their research, they were observing the concept of love with prototype approach by asking the respondents to list as many as possible the words which are correlated to love and by asking them to give the ratings to define the prototype of the category. the other researchers such as Terzino (2007)about forgiveness concept across culture, Lambert et al. (2009) about how people perceive gratitude, May \& Fincham, (2018) about how deity is represented, Amrullah (2018) about staple foods in Indonesia, Bharara et al. (2019) about the concept of wellbeing among adolescents and Ahdiani \& Kurniawan $(2020,2018)$ about prototype of kuliah/studying in university and the concept of successful college student and the type of research done by Ahdiani \& Kurniawan (2020) is similar to research done by Coleman \& Kay (1981) which tried to observe the prototype of word lie by asking the informants about the word lie by providing the illustration about lying. By reviewing those articles about prototype, this paper has the similar aim as what Fehr and Russell conducted on their research by using free listing method and centrality ratings. However, in completing the task, the respondents were given limited time and the further questions were added to confirm that whether language is still seen as an separated and disconnected part from culture and how the respondents viewed their own language, Bahasa Indonesia and regional language, compared to another language and in this case is English.

\section{LITERATURE REVIEW}

The theory of prototype was developed by Rosch which focuses on two fields semantics and syntax (Taylor, 2015). In semantics, this theory is used to analyze the membership of categories (Cruse, 2014) and is the opposite of definitional view about concept when any word which has the same concept will be seen as the the same categories (Lehrer, 2014). However, in the theory of prototype semantics, the categories are defined by their properties, the less the property, the farther their position from central member and this is called peripheral member of category (Ungerer, 2006). In this types of research, the informants are asked to mention member of a category and the best example of the category is the most 
frequently mentioned in the list and after that the informants are asked to judge which of the following member is close to the center of category; moreover, best example of the category is recalled faster than the peripheral member (Cruse, 2014).

Prototype is included in semantics because it is related to the experience in storing the objects in the certain categorization (Riemer, 2010, p.224) The concept of culture is stored by these teenagers through many ways which can be from the way of learning, the book they read, and so many others. Therefore, this prototype is so much related to the context or context dependent (Hampton, 2016, p.133). Because of that, prototype theory is defined as the prototype effects to know about (in this research which is limited to) goodness of exemplar ratings (Riemer, 2010). This is defined like this because not all words in natural language work as a concept in prototype structure (p.236)

\section{RESEARCH METHOD}

This definition about the prototype leads to the use of the methods in collecting the data and analyzing the data. In the methods in collecting the data, it is divided into two steps. The first step is called as free listing which is frequently used in cultural study which relates to semantic domain (Schrauf \& Sanchez, 2010) and this step tried to assess what 47 respondents with age range 18-20 years old think about what culture is by listing as many as they can (Hampton, 2016, p.129), but before they do the task, the instruction which makes them understand what they have to do was given. The instruction is that first they should think of fish and mention what should be categorized as fish and they started to mention what they think it is fish. After that, they were asked whether they understand about what they should do or not. If they do not, the second example was given. The second example is that using bird as the topic of free listing. They would do the same as the first example about fish earlier.

Then, they were asked to list as many as they can about what should be included as culture; this instruction was followed by an explanation that there is not about right or wrong. This task was done for about a minute. The time limitation here is for testing the recency effect. The more recent the words they use, the faster the words will appear. After that they were given a question whether they are capable of showing one of their regional cultures, and if they can they should mention what kinds of the culture they are capable of. After that all of those results were gathered and a week later the second step was started.

The second step is about giving the 52 respondents 40 objects from two categorizations to be judged (Hampton, 2016, p.129). However, before they judged those objects they were asked to answer one question which should be continued if the answer is 'yes'. The question is that whether they are capable of doing one of Indonesian's cultures, and if they were capable of doing that, they should mention it and self-evaluate the level of mastery. After that they were asked to do the judge those objects. The objects chosen are the examples of culture which was collected from the previous method and the examples of previous data collecting method. The reason why two categorizations were asked is that to make sure that the informants were not too exposed in one categorization which may make them difficult to judge the other objects in the same categorization. The informants were given a limited 
time to do this task. The limited time is 1 minute to finish the ten numbers and they need four minutes to judges 40 numbers. After they judged all of those objects which should be judged how good those objects are as the example of the mentioned categorization, they were asked to answer five questions.

The first question is that about their hometown, and the second question is that whether they are capable of doing one of their regional cultures. If they answered 'yes' in the second question, they should continue to answer the third question which two phrase is preferable for them. The first phrase is Anak zaman sekarang or Kids zaman now, and they were asked which name is better for a restaurant. The first name is B\&C Restaurant which stands for Beef and Chicken Restaurant and RM Daging Sapid an Ayam which has the same meaning as the first name but this name is in Bahasa Indonesia. These questions were asked to know how far the English gives the effect to the Bahasa Indonesia, especially among the teenagers.

After all of those steps were conducted in collecting the data, the analysis of these results was started. The analysis of these results will be based on the numbers gathered from the first and second steps of collecting the data. After those numbers collected, then, the discussion was started by combining the results of those two steps. In addition, the elaboration of the first and second result of the method will hopefully be the mirror to depict the trend and tendency of teenagers about their own culture and their own language.

\section{RESULT AND DISCUSSION}

This part will be divided into two parts. The first part is the result of the first step of the data collection and the second part is the result of the second step of the data collection. After those results were explained, the combinations of those results will be elaborated together to get the perspective of culture among the teenagers by emphasizing language as the integral part of it.

\subsection{Free Listing Method Results}

In the free listing method, there are so many examples of culture mentioned by the respondents. Those examples of the culture then were counted and were ranked based on the frequency of those examples were mentioned by the respondents. Here is the table which shows the result of the first method.

\begin{tabular}{cccc}
\hline Example of Culture & Rank & Freq. & Respondents \\
\hline Traditional dance & 1 & 41 & 33 \\
Traditional costume & 2 & 23 & 22 \\
Habit & 3 & 21 & 11 \\
Custom & 4 & 18 & 15 \\
Traditional music instrument & 5 & 17 & 15 \\
Language & 6 & 16 & 16 \\
Traditional food & 7 & 14 & 14 \\
Funeral rites & 8 & 13 & 6 \\
Folk music & 9 & 8 & 7 \\
Historical building & 9 & 8 & 6 \\
Traditional architecture & 10 & 6 & 6 \\
\hline
\end{tabular}

Table 1 . The result of free listing method 
The table 1 above shows the top 10 of the example of culture based on frequency which was taken from free listing method. It shows that the position of language is out of the top 5 because it is only mentioned 16 times by the respondents. This also shows that the respondents even do not acknowledge that the regional language is the part of the culture which should be worth to mention in case of the importance of mastery. It is shown by the result of question asked to the respondents. The question is that if they master one of their regional cultures, and the result is surprising because only 6 respondents out of 47 respondents acknowledge that their regional language is the part of the culture they master. Twelve respondents stated that they were able to do traditional dance and nineteen respondents acknowledge that they do not master any of cultures.

This result shows that the best example of culture is traditional dance because it has 41 frequencies mentioned by 33 respondents out of 47 . It mean that $70.21 \%$ respondents choose traditional dance as the best example of culture while traditional costume obtained $2^{\text {nd }}$ rank with 23 frequency with 22 respondents or equal to $46.80 \%$. Meanwhile, when we look at the respondents who choose language as the part of culture, it only obtains $6^{\text {th }}$ rank with 16 frequency and 16 respondents or equal to $34.04 \%$.
The table 1 simply shows that the teenagers know traditional dance more than language because in this case, traditional dance was mentioned many times not in the form of its general categories, but it was mentioned in the form of its member such as Pendet Dance, Jaipong Dance, Reog Ponorogo, and many others. However, language is only mentioned as its general name or in Indonesia it is known as bahasa and bahasa daerah as the member of bahasa itself. This might be the reason why the teenagers nowadays tend to learn other languages than their mother tongue and their national language. They seem to ignore language as the part of culture which should be learned. It should be noted that the students who partake this research are registered as the students of language department who should have more concerned on language.

\subsection{The Result of Judging the Categories Example}

The result of the judgment of the categories example is rather different from the first one. The number in this result is achieved by counting the mean of the semantic scale types (1-7 scales). Every informants who were asked to rank the objects of categories from 1-7 based on the goodness of those objects as the example of the categorization. Here is the table of the result.

\begin{tabular}{ccc}
\hline Example of Cultures & Rank & Mean \\
\hline Traditional costume & 1 & 6.725 \\
Rites & 2 & 6.613 \\
Traditional Dance & 3 & 6.596 \\
Language & 4 & 6.5 \\
Traditional building & 5 & 6.46 \\
Politeness & 6 & 6.134 \\
Traditional music instrument & 7 & 6.07 \\
Historical building & 7 & 6.07 \\
Stand in line & 8 & 5.94 \\
\hline
\end{tabular}




\begin{tabular}{ccc}
\hline Folk music & 9 & 5.67 \\
Smile & 10 & 5.57 \\
\hline
\end{tabular}

Table 2. The result of categories example judgment

The result shows in the table 2 above shows that the mean of judging the examples of culture has different result from the free listing method explained in 2.1. Traditional dance in the previous method is in the first rank while in the second method it is in the $3^{\text {rd }}$ position. Meanwhile, traditional costume can rise from second position into the first position and rites from $8^{\text {th }}$ position in the previous method can level up into second position. Language also has changed the position from $6^{\text {th }}$ position into $4^{\text {th }}$ position.

In addition, the second method is also followed by one opening question and three closing questions. The opening question is that whether they are able to do one of Indonesian cultures and the closing question is that whether they are able to speak their regional language where they were raised or born. The opening and closing question in the second method form is used to know the perspective of teenagers on language use developed nowadays in society. The result of the opening question whether they are able to do one of Indonesian cultures is that 6 out of 52 respondents answer that they are able to do their regional language where they were raised or born, and 19 out of 52 respondents admits that they are able to do traditional dance; while 7 out of 52 respondents said that they are able to play traditional music instruments such as gamelan, angklung, and other musical instruments. The rest of them, 16 respondents says they cannot do one of Indonesian cultures and 4 respondents they acknowledge that they are able to make a batik, sing a song, and deliver a speech.
The three closing question which the first question is whether they are able to speak in their regional language where they were born or raised, and the second question is whether they choose anak jaman sekarang or kids jaman now as the preferable phrase for writing an article title or the language use with their friends, and the third is which phrase is more preferable for them and more attractive for costumer between $\mathrm{B} \& \mathrm{C}$ Restaurant or RM Daging Ayam dan Sapi. The first question result is 47 out of 52 respondents are able to speak their regional language, while 5 of them are unable to do so, and the mean of mastery level on their regional language based on the self-assessment is 5.35 in 1-7 scale. Meanwhile, the result of the second question is that the respondents who prefer to say kids jaman now is 15 out of 52 or equal to $28.84 \%$ and who prefer anak jaman sekarang is 37 out of 52 or equal to $71.15 \%$. Moreover, the result of the third question is that 27 out of 52 or equal to $51.92 \%$ respondents are preferable with English name of restaurant while 25 out of 52 respondents or equal to $48.07 \%$ chose the otherwise.

\subsection{Between First and Second Method}

It can be noted that the result of the first method, free listing method, is not the same as the second one and language as the example of culture change its position from $6^{\text {th }}$ to $4^{\text {th }}$. Although there is a two levels change in language, the result of other questions related to whether the respondents are aware that language is a part of culture are still far from satisfying. This research indeed has an aim to know the perspective of culture among the 
teenagers; however, the language is the focus of discussion in this case because of the problem faced by Indonesians regarding to the language legacy which started to be a worrisome.

In the result of the first method, free listing method, language is positioned in $6^{\text {th }}$ because it is only 16 respondents with 16 frequencies and the question following this method is which kinds of culture the respondents they are able to do is answered with 6 respondents or equal to $12.76 \%$ answered that they are able to speak their regional language which means that they recognize that language is the part of language they master. Meanwhile, the other respondents who said that they master traditional dance are 12 respondents or equal to $25.53 \%$ and 19 respondents or equal to $40.4 \%$ said that they are unable to do one of examples of the culture.

As what mentioned earlier, the definition of culture which may include everything those teenagers learned when they were child is still not understood by them because there is $25.53 \%$ respondents who said they cannot do anything regarding to the cultural legacy including their own language. Although this result cannot depict all of teenagers in Indonesia because it will need massive samples to obtain the more representative result, this result may give an insight to the bigger research and may depict the partial trend and tendency of Indonesian teenagers in recent years.

In the second method, however, the result is rather different from the first result because it might be affected by many factors. The first factor is that, which has mentioned before, the respondents in the first and second method are the same so they might have an idea what they will do. The second factor is the span of time from first method to second method is not too far so that the respondents might be affected by the first method. Although the rank of some examples of cultures change, the result on the same question whether they master one of Indonesian cultures are still the same on language. In the previous method, the respondents who answer they are able to speak one of Indonesian languages are only 5 out of 47 respondents or equal to $10.63 \%$ and in the second method 6 out of 52 respondents which equals to $11.53 \%$. The gap of the acknowledgment of language as one of cultures they should master between first and second method is only $0.9 \%$. This small difference which only rise $0.9 \%$ is to prove that although language has $4^{\text {th }}$ position in second method from $6^{\text {th }}$ position in first method, it does not change its position in the respondents mind that language is not the important example of culture to be mastered.

The perspective on language based on the first and the second result also affect the closing questions in the second method questionnaire form. In it there are three closing questions which each of them ask whether they are able to speak their regional language where they were born or raised and if yes then how good they master them. The first closing question result is that there are 47 respondents from 52 or equal to $90.4 \%$ who admit that they are able to speak their regional language with 5.35 level of mastery based on their selfassessment and 5 respondents admit that they are unable to speak their regional language; however, when these 47 respondents who said that they are able to speak their regional language were asked whether they master one of Indonesian cultures only 6 respondents admit that language they speak is the part of culture they master. 
The definition of culture stated by Tylor (2016) seems not be included in 52 respondents' answer because the answer of the question whether they are able to do one of Indonesian cultures or not was mostly able to perform traditional dance, play traditional music instrument, and sing folk song, while language is only answered by 5 respondents in the question in first method questionnaire and 6 respondents in the question in the second method questionnaire. This proves that the 52 teenagers who become the respondents in this research still do not realize that culture is whatever they learnt when they were child in the area they were raised.

The misconception that culture is what they can perform on stage might be affected by the events held by the governments or the society which emphasizes on the examples of culture which can be performed, and these events might be the basic knowledge for them that culture is what they can show to the public. Although these events cannot be blamed, the authorities or the people who know about what the culture is should give more insights to them that culture will include the society's beliefs, values, and habits. Furthermore, culture also includes language because language in this case is the bridge and the torchlight to

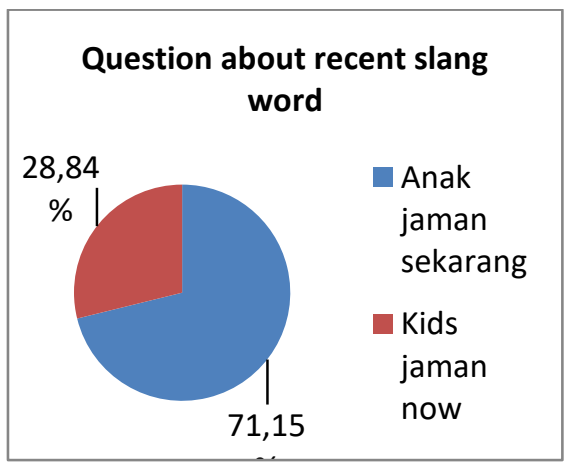

Diagram 1. Question which are preferable between 'anak jaman sekarang' and 'kids jaman now' understand the structure of culture in a society (Moore, 2009, p.90)

What Moore stated above was taken from Boas' idea about language which was further elaborated by Jakobson. Boas' idea about language is that language is the most important factor to gain an access to ethnological knowledge of the society observed because every word spoken by the native speakers can give source of information (Moore, 2009, p.89).

\subsection{Cultural awareness to protect linguistic legacy}

By understanding that language is the important part of preserving the culture because through language the society can prolong their culture to be shared to the next generation, the society and media should be more aware of how to protect their own language from the effect of globalization in which all languages can be a threat to existing language. The globalization which is unavoidable should be faced wisely and carefully to preserve the language. The result of the closing question which will be described in diagram below shows that the tendency of teenagers towards the other languages, especially English should get more attention to protect the national language from the degradation.

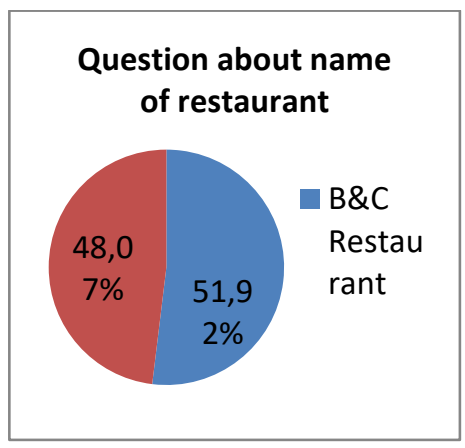

Diagram 2. Question which are more attractive between English and Indonesian name for restaurant 
The result of that question is not quite surprising because the phrase 'kids jaman now' has been spread through media and television and even in online newspaper articles. Because of the spread of this phrase, the other phrase with the same structure as it is began to appear and this is the problem that should be worried. If the media keep spreading the phrase like this and never give a proper education to the viewers, the new phrase using code mixing like this will be appear someday because this ignorance to the foreign lexicon to be used in language use such as kids, president, teachers, and even parents in the beginning and now in the ending of the phrase can be seen as the way of encouraging the teenagers to create something new but unacceptable in their own language.

The more convincing of the negative encouraging of this creation is that the appearance of other phrase and words such as mantap soul, unfaedah, curigation, and many other which also gain so much popularity among teenagers. The misuse and miscreation of the slang words among the teenagers can also be the depiction of how the teenagers perceive English is higher in status than Bahasa Indonesia and this result is also supported by the research result by Abdurrahman (2020) which describes that people who speak English either in daily interaction or social media are regarded to have more intelligence to who do not (p.27) although the type of insertion in codemixing is perceived negatively because insertion type in code-mixing is considered unable to speak English correctly (p.28) This will be more dangerous if those phenomena are kept to crawl and this will be more dangerous if the perception of English keep raising in Indonesian society.
The use of English in advertisements and in the name of hotels and products are also the problems which still beyond Indonesian's attention. Although the government has regulate the use of Bahasa Indonesia in public places such as for advertising, trading, and also sharing information through mass media (UU No. 24, 2009), the effectiveness of this application is far from satisfying because there are so many advertisements and products use English in order to catch the customer's attention although Bahasa Indonesia nowadays can compete with many global products (Arifin, 2015). In teaching foreign language, for example English, should be also emphasizes on teaching local wisdom to maintain their identity as Indonesians (Albantani \& Madkur, 2018) so that the mandate from UU No. 20, 2003 can be applied in every level of education in Indonesia which states that national education has its root in religious and cultural values to face global challenge.

The way to preserve Bahasa Indonesia can use the proposed method by Moeliono (1985). Although this book was published 33 years ago, the proposed method in preserving Bahasa Indonesia by doing counseling to the public is the best way still now because the introduction part and discussion part has clearly explained the effect of English towards the teenagers which is mostly spread by media and advertisements can be so devastating so that the media and business company should uphold the regulation in using Bahasa Indonesia. The method proposed by Anton Moeliono which can be divided into three ways in preserving language is that firstly, to change the attitude towards Bahasa Indonesia and to give counseling towards the people 
which can be conducted through mass media, by the authorities, or by special counseling (Moeliono, 1985) using internet to spread the information about the standard form of Bahasa Indonesia.

\section{CONCLUSION}

The perspective of the teenagers towards culture may depict the knowledge of the teenagers about the culture which tends to see culture as the performable action. These results also may give the picture how teenagers perceive language as the part of the culture which is not admitted as the part of culture which should be mastered or if they mastered their regional language, they seem to disagree that language is categorized as one of Indonesian cultures they are proud of. It can be seen from the lower number of respondents who stated that their regional language mastery as the Indonesian culture they should master. Moreover, the result of the preferable phrase which is commonly used by teenagers is quite worrying because in the short span of time the tendencies of the teenagers to use the phrase $(\mathrm{N})$ jaman now are $28.84 \%$ and if this result is ignored, the more worrying problems will appear and it will give a bad effects to the preserving process of Bahasa Indonesia among teenagers. Therefore, media which give so much contribution to the language use in society should be more actively promoting Bahasa Indonesia as the official language to be used in public rather than using English which has gain its international position.

\section{REFERENCES}

Abdurrahman, N. H. (2020). Perception towards the code-mixing of Bahasa Indonesia and English. CAPEU Journal of Education, 1(1), 21-30. Ahdiani, U., \& Kurniawan, M. H. (2020). The concept of successful college student in Yogyakarta. Journal Basis, 7(1), 67-79. http://ejournal.upbatam.ac.id/index .php/basis/article/view/1801

Ahdiani, U., \& Kurniawan, M. H. (2018). Prototype semantics of the concept of word 'kuuliah' among college students. In $\mathrm{H}$. Kustanto (Ed.), the 4th Hamzanwadi International Conference on Education: Elevating Human Resouruces through Education, Language, and Culture (pp. 140150). Universitas Hamzanwadi.

Akmajian, A., Demers, R. A., Farmer, A. K., \& Harnish, R. M. (2010). Linguistics: An Introduction to Language and Communication (6th ed.). MIT Press.

Albantani, A. M., \& Madkur, A. (2018). Think globally, act locally: the strategy of incorporating local wisdom in foreign language teaching in Indonesia. International Journal of Applied Linguistics and Literature, 7(2), 18.

Amrullah, L. (2018). Semantic prototype of Indonesian staple foods. Litera, 17(2), 153-161.

Arifin, E. Z. (2015). Implementasi Pasal 36 Undang-Undang Bahasa. Jurnal Pujangga, 1(2), 1-23.

Bharara, G., Duncan, S., Aaron, J., \& Hiunckson, E. (2019). A prototype analysis of New Zealand adolescents' conceptualizations of wellbeing. International Journal of Wellbeing, 9(4), 1-25.

Coleman, L., \& Kay, P. (1981). Prototype semantics: The English word lie. Language, 57(1), 26-44.

Cruse, D. . (2014). Prototype theory and lexical semantics. In $\mathrm{S}$. $\mathrm{L}$. Tsohatzidis (Ed.), Meanings and Prototypes: Studies in Linguistics Categorization (pp. 382-402). Routledge. 
Eriksen, T. H. (2006). What is Anthropology? Pluto Press.

Fehr, B., \& Russell, J. A. (1991). The concept of love viewed from a prototype perspective. Journal of Personality and Social Psychology, 60(3), 425-438.

Fermansyah, V. D. (2017). Saking kocaknya! 6 bahasa kids jaman now ini taka da di kamus, nomor 3 bikin gregetan. Tribunnews. http://m.tribunnews.com/amp/lifest yle/2017/12/09/saking-kocaknya6-bahasa-kids-jaman-now-ini-takada-di-kamus-nomor-3-bikingregetan? page $=4$.

Hampton, J. A. (2016). Categories, prototypes and exemplars. In $\mathrm{N}$. Riemer (Ed.), Routledge Handbook of Semantics (pp. 125-141). Routledge.

Holmes, J. (2013). Introduction to Sociolinguistics. Wellington.

Isnaeni, M. (2017). Kids jaman now. Media Indonesia. http://mediaindonesia.com/read/det ail/129472-kids-jaman-now.

Jiang, W. (2000). No Title). the relationship between culture and language. ELT Journal, 54(4), 328-334.

Kirkpatrick, A. (2012). English in Asean: implications for regional multilingualism. Journal of Multiligual and Multicultural Development, 33(4), 331-344.

Lacey, J. (2013). Considerations on English as a global lingua franca. Political Studies Review. https://doi.org/doi: 10.1111/14789302.12004

Lambert, N. M., Graham, S. M., \& Fincham, F. D. (2009). A Prototype analysis of gratitude: Varieties of gratitude. Personality and Social Psychology Bulletin, 35(9), 1193-1207.

Lehrer, A. (2014). Prototype theory and its implications for lexical analysis. In S. L. Tsohatzidis (Ed.), Meanings and Prototypes: Studies in Linguistics Categorization (pp. 368-381). Routledge.

Matsumoto, D., \& Juang, L. (2003). Culture and psychology. Wordsworth Publsihing.

May, R. W., \& Fincham, F. D. (2018). Deity representation: A prototype approach. Archieve for The Psychology of Religion, 40(2-3), 258-286.

May, S. (2015). The problem with English(es) and linguistic (in)justice. Addressing the limits of liberal egalitarian accounts of language. Critical Review of International Social and Political Philosophy, 18(2), 131-148.

Moeliono, A. (1985). Pengembangan dan pembinaan bahasa: Ancangan alternatif di dalam perencanaan bahasa. Djambatan.

Moore, J. D. (2009). Visions of culture: An introduction to anthropological theories and theorists (3rd Ed.). Altamira Press.

Onishi, N. (2010). As English spreads, Indonesians fear for their language. The New York Times. https://www.nytimes.com/2010/07/ 26/world/asia/26indo.html

Riemer, N. (2010). Introducing Semantics. Cambridge University Press.

Rochmawati, A. R. (2018). Jadi presiden zaman now, Jokowi harus siap dikritisi. Viva. http://www.viva.co.id/berita/nasion al/1003483-jadi-presiden-zamannow-jokwi-harus-siap-dikritisi

Rosch, E., Mervis, C. B., Grey, W. D., Johnson, D. M., \& Boyes-Braem, P. (1976). Basic objects in natural categories. Cognitive Psychology, 8, 382-439.

Schrauf, R. W., \& Sanchez, J. (2010). 
Age effects and sample size in free listing. Field Methods, 22(1), 7087.

Taylor, J. R. (2015). Prototype Theory in Linguistics. In International Encyclopedia of the Social \& Social Behavioral Sciences (2nd ed., pp. 286-289). Elsevier.

Terzino, K. A. (2007). Culture and forgiveness: a prototype perspective. Iowa State University.

Tinsley, T., \& Board, K. (2013). Language for the future: Which languages the UK needs most and why.

https://www.britishcouncil.org/site s/default/files/languages-for-thefuture-report.pdf

Tylor, E. B. (2016). Primitive Culture. Dover Publications, Inc.

Ungerer, F. (2006). An Introduction to Cognitive Linguistics (2nd ed.). Pearson Longman. 
